\title{
Male relationship building that makes women roll their eyes: Implications for social work
}

\author{
Anaru Eketone
}

Anaru Eketone (Ngati Maniapoto, Waikato) is a lecturer in the Department of Social Work and Community Development at the University of Otago.

Since 1994 I have worked in three sectors dominated by women: health promotion, social work and social work education. One of the tasks when working in these female-dominated fields is that to maintain any sort of credibility you need to act and talk in ways that do not offend women.

One of the personal challenges I have faced is to work in these areas and still find ways of meeting the need I have to still be a 'bloke'. Even within my own household I am the only male (that includes the dog), so privately you hold on to your masculinity, i.e. the socially defined roles, through being a husband and father. But I have also found the need to express myself physically - very occasionally through physical work, but more often through sport, mau rakau and even watching physical sport. (For Valentine's Day I bought my wife a season ticket to watch rugby at Carisbrook; she returned the favour by giving me a season ticket to our local symphony orchestra.)

There is not a great deal written about social work and Maori masculinity. This article seeks to discuss issues around some of the differences in the ways that many males choose to interact with each other and the implications this type of masculinity has for social work practice. Four examples will be described of a particular version of masculine ways of relating, which will be followed by a discussion.

\section{Story 1}

My uncle was telling me a story about how he was helping one of his good mates in Thames, to round up some cattle into one of the yards on the farm. My uncle was in the middle of the yard when something went wrong and spooked the cattle. He got knocked to the ground and was trampled. His mate rushed over to him, saw him lying on the ground trampled into the mud and filth, stood over him and said, 'Die, ya bastard'. Without a word of a lie, as my uncle told me this story I am sure I saw him wipe a tear from his eye, so moved was he by the mateship exhibited by his friend.

\section{Story 2}

I remember watching a programme on rugby in the late 1990s where Phil Kearns, the famous Australian rugby hooker, was discussing his return to rugby after a long injury. His first game back had been for the New South Wales Warratahs versus the Canterbury Crusaders. It was 
a special moment for Kearns, as he had thought that because of injury and rugby politics, he might never play rugby at that level again. It came time for the first scrum where one of the opposing props was the infamous All Black hard man, Richard Loe. As the scrum came down, Loe turned his head and smashed it into the side of Kearns's head, making him feel dazed and disoriented. Through the pain he heard Loe say in a cheerful voice, 'Welcome back Kearnsy'. As Kearns related this story, towards the end with a big smile on his face, he got a little choked up as he was obviously touched and moved by Loe's welcome.

\section{Story 3}

A man in his fifties who had always struggled because of the violence he had experienced as a child, was talking to a community worker, bemoaning his upbringing. As he related the story, the community worker who was a good friend of his and from the same iwi, said 'Get over it, it was 40 years ago. I remember you as a kid, you were a spoilt brat, your mother always spoilt you.' The man sat upright and said, 'Yeah you're right it was 40 years ago'. From that moment his life began to change for the better as he finally let go of that pain.

\section{Story 4}

I volunteered full-time for three months at a Maori social service organisation run by Maori men. The ribbing was ruthless. Anything dumb that anyone did or said was mercilessly exploited to its maximum. Thus was created a cycle of humiliation and revenge that was a source of constant hilarity. It brought the workers together into a tight-knit group where people had a great time working and socialising together. It was a time and place where workers looked forward to the smoko and lunch breaks to continue what was in effect relationship building and bonding.

\section{Discussion}

While a number of women may roll their eyes at the apparently clumsy ways in which male relationships can be formed and expressed, many men would read these stories, smile and nod quietly to themselves. One of the common threads in these stories was that this type of expression was based on strong relationships, where there was humour, but where it could only have occurred in a context where people had a genuine concern for one another.

This type of expression has strong links to a rural masculinity described by Hokowhitu (2003). He spoke of how in his home town a proof of physicality was needed to establish a male identity and how this was expressed through activities such as sport, pig-hunting, drinking, diving for kai moana and 'refusing to yield to physical pain'. In his town these were the marks of a true masculinity. Hokowhitu deconstructs these values and warns of the pervasive nature of them and how they can be oppressive and prevent other forms of masculinity from being expressed, such as being strong academically.

At the University of Otago there are few men enrolled to do social work. By the third and fourth years there is usually a ratio of one man to 10 women. Some men find the constant constraints on their behaviour and language because of the gender imbalance a struggle. I can remember talking to one young tane who spent all day in a class full of women but was flatting entirely with males. I asked if they did things like 'pile' on one another just for fun. 
He looked at me with a fear in his eyes, obviously thinking, 'should I admit to that' but was relieved to hear how occasionally in my younger days I used to enjoy doing the same thing, although I would nearly always come off second best. (It is important to note that this is not about the type of behaviour that is bullying or exploitive. I'm referring here to the types of behaviour that are reciprocal and used to include rather than ostracise or marginalise.)

Many men have developed ways of relating and find substitutes for the lack of desire or the ability to talk. As a teenager my father found it difficult to talk to me, I was the brooding type, refusing to talk unless it was to argue. My father got around that through playing together. Every evening in the summer we played cricket or golf, and in the winter it was chess or playing cards for my pocket money. So even though on one level the relationship was difficult, on another it became very strong as we spent a lot of time together in situations where words weren't important.

It is important to acknowledge what is, i.e. that there are still many men who are comfortable and prefer relating in these ways. They enjoy it, and rightly or wrongly, it contributes to, and underpins a sense of self and identity. While these statements invite a feminist critique, the issue here is not the behaviour but how that behaviour is interpreted by those it affects. While these approaches can reinforce physical prowess as a marker of masculinity, often it is just as satisfying to those on the losing side as the winning side. What is satisfying is the expending of physical energy and the relationship building that is taking place.

However, this type of communication and relationship building is controversial and fraught with problems. Firstly it assumes homogenous ways of viewing masculinity. As such it can subordinate other expressions of masculinity, particularly forms of homosexuality defining them as feminine and consequently inferior (Leach, 1994). It also sees men as locked into one way of being where physicality, staunchness and being the strong silent type continues to inform and underpin a hegemonic masculinity (Hokowhitu, 2003, 2004). This 'hegemonic masculinity' built on physical, social and political power has been at the forefront in the oppression of women in the western world as well as to many men (Leach, 1994) and is, of course, to be rejected.

Another weakness of this physical masculinity approach is that it assumes and values physical and mental strength. Therefore, to show physical or mental weakness can be threatening to some men's view of themselves. In a recent study on hindrances to men accessing mental health services, one of the significant barriers was that by acknowledging weakness men felt emasculated and so sought to avoid facing up to their problems until it was often too late (McKay, 2007).

In the opening paragraphs I had to prove my credentials as a 'masculine male' with the mention of sport, mau rakau and physical work. One event that horrified me was when one of my daughters told her flatmates that they didn't need to be scared of me because I was a big teddy bear. How can I keep up the facade of staunchness with that sort of recommendation?

Masculinity in social work can be problematic, especially as the last quarter of a century has seen a feminisation both of the workforce and what is considered good social work practice. How then do we manage this form of physical masculinity when it appears it is not 
valued in social work? There is some emerging evidence that while it can be protective to maintain good mental health, it becomes a liability when things are starting to fall apart, and becomes a huge barrier to men asking for help when they really need it (McKay, 2007).

There is greater hope for Maori men than non-Maori men. There is not such a sanction against showing emotion and therefore vulnerability:

- Ruben Wiki kissing a fellow player on the forehead in a rugby league game.

- Corporal Willie Apiata obviously moved when talking about the support he had received upon winning the Victoria Cross for New Zealand.

- Norm Hewitt sobbing while publicly apologising for indiscretions on a rugby trip.

- Any number of men shedding a tear or two at the tangi, not just of a loved one, but anyone's loved one.

These examples show there are more dimensions to what could be called the physical New Zealand Maori male.

What then are the implications for social work and social work education?

- We need research on the forthright ways of dealing with issues that many men prefer to use particularly with other men, but feel hamstrung over what is seen as a reliance on sensitive ways of dealing with things.

- We need to recognise the wide variety of communication strategies and the depth of relationship that these can form.

- We need to be aware of the role of humour in relationship building.

- We need to realise that there is still a role for physicality particularly in younger men.

- We need to be reminded that men in social work do not have to be locked into nurturing or passive roles to be effective social work practitioners. In fact, men have the option to use a vast array of methods, strategies and relationship-building techniques.

However as tane, along with the opportunities this breadth of strategies gives, there is a greater pressure to ensure that we are constantly reflective in our practice, examining the implications and consequences of the way we work:

- We need to ensure that our practice and our behaviour do not contribute to the oppression or marginalisation of both women or other expressions of masculinity.

- We need to be vigilant that our behaviour and practice in no way condones any form of violence or control.

- We need to watch that our behaviour 'with the boys' doesn't create a situation where others feel locked out, particularly in our workplaces.

- We also need to role model and promote a culture of the acceptance of Maori male vulnerability so that tane may get the help and support they need when they need it without stigmatisation. This is a complicated task of exhibiting vulnerability and sensitivity as well as bravado and staunchness; one of the blokes but able to be approachable to discuss deeper issues.

Whether through biology or environment, a significant number of New Zealand men have developed ways of communicating that express feelings and emotions, that may not be as 
deep as a Shakespearian sonnet, but do allow many men to express themselves in ways that they value and makes them feel comfortable. While there are connections of this approach to a hegemonic masculinity that has marginalised and disempowered, male social work practitioners should not feel guilty about it. Instead they should develop a reflective practice which will enable them to have a wide range of tools for dealing with other men. Even if our female colleagues do occasionally roll their eyes.

\section{References}

Leach, M. (1994). The politics of masculinity: An overview of contemporary theory. Social Alternatives, 12(4), 3637.

Hokowhitu, B. (2003). Maori masculinity, post-structuralism, and the emerging self. New Zealand Sociology, 18(1).

Hokowhitu, B. (2004). Tackling Maori masculinity: A colonial genealogy of savagery and sport. The Contemporary Pacific, 16(2), 259-284.

McKay, J. (2007) Men's mental health: What helps or hinders men's access to a community mental health team. A thesis submitted to fulfil the requirements of the Master of Social Welfare, University of Otago. 